\title{
Research on Action Oriented Teaching Model for College English in Applied Talents Training
}

\author{
Yumei Zhou \\ Teaching and Research Institute of Foreign Languages, Bohai University, Jinzhou, 121013, China \\ 271742254@qq.com
}

Keywords: applied talents training; college English teaching; action oriented teaching model; theoretical basis; teaching system; teaching process

\begin{abstract}
The goal of College English teaching is to cultivate student's comprehensive ability of English application, and to have the ability of English practice, innovation and intercultural communication. At present, there are many problems in College English teaching, which hinder the further improvement of the quality of College English teaching, are not conducive to the applied talents training. This paper studies the application of action oriented teaching model in College English teaching, in order to improve the quality of English teaching and cultivate student's English application ability. The research content of this paper is based on the action oriented teaching model, analyzes the superiority of college English using the action oriented teaching model, constructs the college English action oriented teaching mode system, and points out the process of college English action oriented teaching mode.
\end{abstract}

\section{Introduction}

College English teaching is an integral part of higher education. College English course is a compulsory basic course for college students. College English is based on the theory of foreign language teaching, with English language knowledge and application skills, cross-cultural communication and learning strategies as the main content, and set a variety of teaching models and teaching methods as the teaching system. The goal of college English teaching is to cultivate student's English comprehensive application ability, especially listening and speaking ability, so as to be able to communicate effectively in English in the future study, work and social interaction, at the same time enhance their autonomous learning ability, improve the comprehensive cultural quality, To meet the needs of social development and international exchange.

An important way to achieve the goal of college English teaching is to cultivate applied talents. Applied talents are relative to the high-level theoretical and academic talents, master the direct application of knowledge, practical ability of talent. The essential characteristics of applied talents are clear professional, practical and high level. Therefore, it is necessary that applied talents not only master the basic theory knowledge and grasp the basic practical skills, but also have comprehensive professional ability and professional quality. According to the characteristics of foreign language as a communication tool, the English applied talents should have the following abilities [1]: first, the ability of foreign language practice, the practical problem in English, the ability to engage in related work; second, innovation, including innovation and innovation awareness; thirdly, intercultural communicative competence, including linguistic competence, communicative competence and integrated cultural competence.

At present, there are many problems in college English teaching, which hinder the improvement of college English teaching quality and are not conducive to the cultivation of applied talents [2,3]. First, teach English as a language knowledge, did not realize that is a kind of application ability. Long-term examination-oriented education, one-sided emphasis on the ability of students to test questions, ignoring the "listening, speaking, reading, writing, translation" and other comprehensive ability training. Teachers pay attention to the content of the text to understand, students in the classroom is difficult to improve the ability of English applications. Teachers system to explain the words, grammar and sentence patterns, lack of vitality of the classroom atmosphere, improper 
teaching methods; second, a single teaching means, ignoring the cultivation of students language skills. College English is a public class at the university level, and many of them use large classes. Because of the large number of students, teachers are difficult to explain according to the characteristics of students, the basic use of "spoon-fed" teaching mode, teachers in addition to lectures, very few organizations related to teaching activities. This model is difficult to stimulate students to learn English interest, leading to the mechanization of teaching process.

To solve the problems existing in college English teaching, cultivate the talents suitable for the needs of the society, we must deepen the teaching reform comprehensively and further clarify the guiding ideology and thinking of higher education and establish the educational concept, quality view and talent concept, change the "teacher-centered, classroom-centered, textbook-centered" class teaching system, promote educational ideas and educational concepts to update, summed up the experience of teaching reform on the basis of the professional structure, personnel training programs, Curriculum structure, teaching content, teaching methods and means, teaching management system and other aspects of a comprehensive reform to meet the needs of application-oriented personnel training. The research content of this article is an important part of the deepening of education reform in order to improve the quality of English teaching and to cultivate student's English application ability.

\section{Action Oriented Teaching Model and Its Theoretical Basis}

Action oriented teaching is the "action oriented" as the main form, give full play to the main role of students and teachers of the leading role in the teaching process, focus on students to analyze problems and problem-solving ability, from the completion of a certain aspect of the "task " as the start, by guiding students to complete the" task " to achieve the teaching objectives. From the process of students receiving knowledge, knowledge comes from practice, in practice, get emotional understanding, after repeated practice can rise to rational knowledge, and go back to practice. The ultimate goal of action-oriented teaching is the change of student behavior, through the exchange and cooperation to solve the practical application of the problem-solving process, both the learning process, but also the process of experience, the teacher from the knowledge of the interpreter to become a consultant or mentor , With the following characteristics: focus on action-oriented, emphasizing learning methods; focus on cultivating interest, emphasizing the spirit of independence; focus on mutual cooperation, emphasizing comprehensive learning. The theoretical basis of action oriented teaching models includes:

(1) Cognitivism learning theory. Cognition is not given by external direct stimulation, but by the external stimulus and the cognitive process within the main psychological process of interaction results. Action oriented teaching model and cognitive learning theory are closely linked, are to explore the relationship between cognitive structure and individual activities, is the organic reflection of cognitive theory.

(2) Constructivism learning theory. Students are not acquire knowledge directly taught by teachers, but learners in the process of social interaction with the help of others, the use of internal knowledge structure and the interaction between the external structure of the object, through the meaning of the way to build. Learning is the learner's active construction of new knowledge, and certainly the teacher's guiding role.

(3) Humanism education theory. The process of human cognition is both the cognitive process and the emotional process. The first condition of the realization of the teaching goal is the intervention of interpersonal and emotional attitudes, which requires teachers to create a sincere, easy-to-understand and understandable learning environment for students in the teaching process, The value of the full understanding on the basis of the formation of a real self concept.

\section{Superiority of Action Oriented Teaching Model in College English Teaching}

College English teaching uses action oriented teaching model, has the following advantages [4,5]:

(1) Improve student interest. Interest is the best teacher, interest is to promote students to learn a 
great deal of motivation. With the interest of learning, learning will be able to produce enthusiasm, you can have a strong learning needs, you can experience the fun of learning. Action oriented model of college English classroom teaching, to fully mobilize the enthusiasm of each student, each student is involved in learning activities, the effective mobilization of the enthusiasm of students, to maximize the potential to deepen the understanding and mastery of knowledge.

(2) Students become the subject of learning. The traditional English classroom for the "spoon-fed" teaching, students have no choice but to accept the knowledge, learning skills and personal perception by teachers ignored. Action-oriented teaching enables students to become learners and subjects of learning, and teachers become learners and evaluators of learning. From "teacher centered" to "student-centered", learners in the classroom learning process to master the dominant position.

(3) Teaching objectives have more targeted. The traditional teaching mode is the teacher has the knowledge or experience of the simple transmission, only the textbooks involved in the brief introduction to the scene, the actual work of the students may encounter the scene is not forward-looking. Action-oriented teaching requires students to complete all aspects of teaching tasks. Task set up to the specific activities of the daily use of English as the main content, classroom teaching has a targeted, real tasks make students feel at home

(4) Advantageous to develop student's English thinking ability. Language is the basis of thinking, only to master the English language, can really think in English. Language can not be separated from thinking, language to rely on the content of thinking to enrich and improve, no language thinking is empty. Action oriented teaching, mobilize the enthusiasm of students thinking, teachers clever questions, through the experience, inspiration and coaching, guide students to creative thinking, and learning interest in the development of English thinking.

\section{Action Oriented Teaching Model System in College English Teaching}

The teaching mode system is the basic structure of knowledge, the framework, the teaching content design, the teaching method design, the teaching process design and the teaching result evaluation of the teaching process. In the perspective of applied talents training, the college English action oriented teaching mode system, centered on students, practice as the center and ability training, emphasizes the idea of learning in action. Not only to the action oriented concept embodied in the English level teaching method level, but also with the concept of action oriented construction with the application of the characteristics of training system, the system structure as shown in Fig. 1 [6].

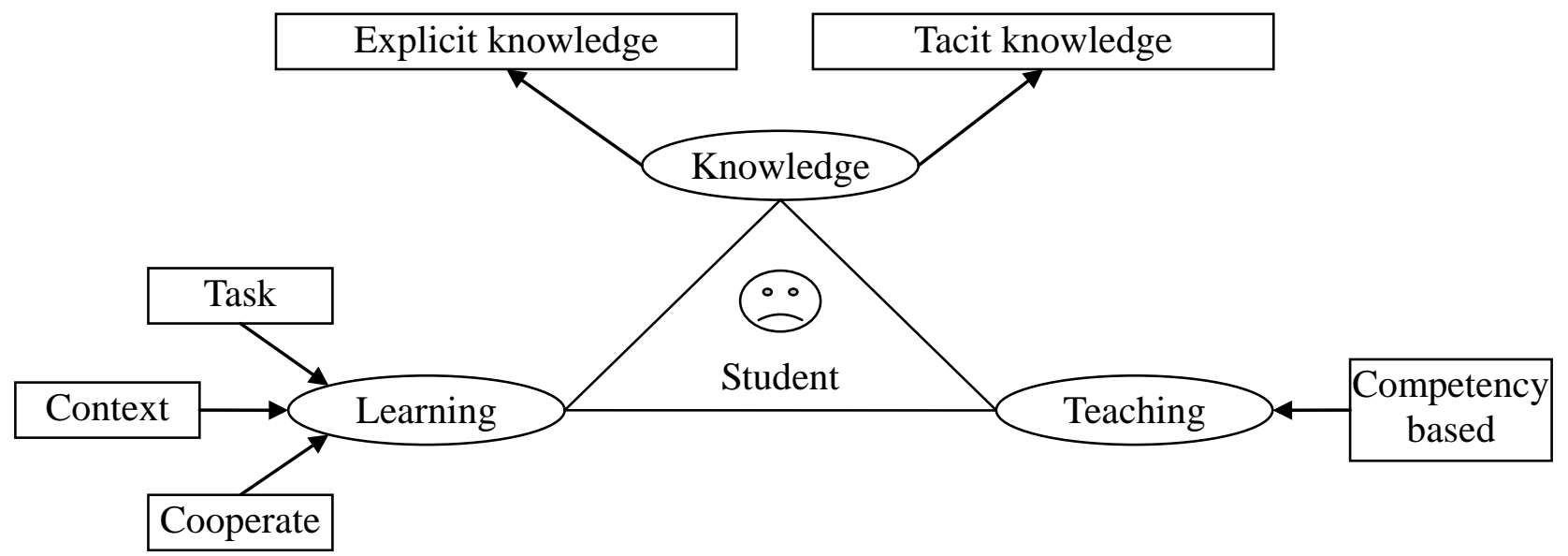

Fig. 1. System structure of action oriented teaching model in college English teaching

In the college English action oriented teaching mode system as shown in Fig. 1, the three links of knowledge, learning and teaching are interconnected and integrated.

(1) Construction of knowledge. It includes explicit knowledge and tacit knowledge. Explicit knowledge can be obtained through oral teaching, textbooks, reference materials, periodicals and magazines, patent literature, audio-visual media, software and databases, which can be easily learned by language, books, text, and databases. Tacit knowledge is often used, but can not be 
clearly expressed through the language of the text or direct transmission of knowledge, in essence, is a comprehension, comprehension and judgment [7]. Explicit knowledge belongs to the category of "knowledge", and tacit knowledge "use" category. In the view of college English knowledge, the combination of explicit knowledge and tacit knowledge is the secret of students 'learning success, which is conducive to the development of students' language coordination and environmental adaptability, and has a unique role in the formation of English skills The Therefore, not only should pay attention to the knowledge of English textbooks, but also improve student's language skills in the actual situation.

(2) Construction of learning theory. New constructivism emphasizes student centered, emphasizing complex learning environment and real learning tasks, emphasizing social consultation and social interaction, emphasizing the positive role of learners in their own constructive meaning. The student centered teaching philosophy requires task-based, situation and collaborative inquiry-based learning, which also forms the basis of the study of the English oriented action oriented teaching system, which is the essence of student centered action oriented learning theory. First, based on the task of learning, show students how to complete the task of behavior demonstration, help students build understanding and development of related problem-solving skills; and then, based on situation learning, practical application of knowledge in the real situation of knowledge, finally, based on cooperative inquiry learning, change "to teach as the main" as "to learn the main", through mutual exchange and collaborative learning, improve student's ability to innovate, develop student's intellectual level.

(3) Construction of teaching theory. With the deepening of modern educational research, people are becoming more and more aware of the particularity of the cultivation of applied talents, and form a more systematic ability-based teaching view. Competence-based education focuses on the knowledge and competencies required for professional jobs, and teaches students' professional competence as the fundamental goal of education, rather than on academic or academic knowledge. It has the characteristics of teaching target behavior, professional teaching content, individualized teaching methods, standardization of teaching evaluation, autonomy of students' learning and marketed of teaching effect. Through the provision of professional knowledge and English ability to match the basic principles, emphasizing the students in the learning process of the dominant position, around the students with the necessary professional English communication skills and learning ability to determine the training objectives, select the course content, design teaching methods and assessment of teaching effectiveness.

\section{Action Oriented Teaching Model Process in College English Teaching}

To develop a scientific and rational teaching process is to promote the implementation of action-oriented teaching model key. The principle of action-oriented teaching process design is that action-oriented teaching is a comprehensive learning activity, and action-oriented teaching is a student's active learning activity. The core of action-oriented teaching is to accomplish an action result that can be used. Action-oriented teaching is based on student interest Organization-oriented teaching; action-oriented teaching requires students to participate in the whole process; action-oriented teaching emphasizes problem-solving ability and application. Following these principles, combined with the application of the concept of capacity building, the College English action oriented teaching process include four stages:

(1) Self-learning stage. Students carry on self-learning based on the guidance program, master the simple knowledge , and knowledge of a holistic understanding. Guidance program is based on the characteristics of teaching knowledge and teaching purpose, according to the student's cognitive level and knowledge and experience, guide students to develop knowledge of the construction of learning programs. The contents of the program include learning objectives, key knowledge, difficult knowledge, learning methods and learning content, etc., is the teaching text common to teachers and students.

(2) Teaching knowledge transfer. The focus of knowledge transfer is the pre-class task design. Pre-class tasks focus on inspiring students to solve the problem of thinking, and guide students to 
actively explore and find the law, and summarized. To design the problem, through the creation of the situation, the teaching difficulties or other knowledge points into the problem put forward, so that students solve the problem at the same time, grasp the teaching difficulties or other knowledge points, so as to develop students to solve problems and learn from each other.

(3) Internalization expansion stage. Teachers spend less time, follow the "first class after school, because of teaching and teaching" strategy, and "knowledge to do what" teaching concept, focus on student attention, explain the key points, difficulties and key points, the subject knowledge points Get the whole understanding. Using the form of mind map, the knowledge of the relevant content of the formation of "knowledge tree", so that students can guide the organic integration of knowledge-related knowledge. Make the student group as the main body, so that students form a group consciously and actively explore.

(4) Summarize and improvement stage. It enable students to self-study and classroom learning to explore the contents of the study systematically and structured, teachers help students to sort out the knowledge, summed up the knowledge framework, problem-solving methods and techniques [8]. In order to consolidate the knowledge we have learned, we can arrange some interesting, challenging and innovative questions. Students who have difficulty in solving problems can arrange some basic questions or moderately difficult questions.

\section{Acknowledgement}

This work is supported by social science fund project of Liaoning province: Research on Action Oriented Teaching Model for College English in Applied Talents Training (L16DYY001).

\section{References}

[1] B. W. Deng, "A study on the Intensive Reading Teaching Model for Cultivating Application Oriented English Talents," Journal of Hubei Correspondence University, vol. 28, no. 9, pp. 180-181, 2015.

[2] F. Fan, "Opportunities and challenges of college English teaching model innovation under the new media," Sun Yatsen University Forum, vol. 27, no. 10, pp. 264-267, 2007.

[3] Lotus Mountain courseware, "On the problems and countermeasures in college English teaching," http://www.5ykj.com/Article/jxlwyylw/31543.htm, 2016-4-23.

[4] F. W. Ye, "Action oriented teaching in English class," Education Forum, vol. 7, no. 41, pp. 260-261, 2015.

[5] J. H. Yang, X. F. Ye, "Feasibility study on the application of action oriented approach in English Teaching," Journal of Harbin Vocational \& Technical College, vol. 22, no. 4, pp. 56-57, 2011.

[6] H. Li, "Construction of action-oriented teaching of higher vocational English," Journal of Shijiazhuang Vocational Technology Institute, vol. 23, no. 5, pp. 15-20, 2011.

[7] G. X. Yu, "A SPA of Tacit Knowledge and Explicit knowledge in Identity, Discrepancy and Contrary," Journal of Xiangfan University, vol. 29, no. 5, pp. 84-87, 2008.

[8] C. L. Jiao, "Implementation Principle and Teaching Organization Process of Action - oriented Teaching Model," Education and Teaching Research, vol. 29, no. 6, pp. 83-86, 2015. 